\title{
Biomagnification of mercury through the food web of the Santos continental shelf, subtropical Brazil
}

\author{
Elizabeti Y. Muto ${ }^{1,3, *}$, Lucy S. H. Soares ${ }^{1}$, Jorge E. S. Sarkis ${ }^{2}$, Marcos A. Hortellani ${ }^{2}$, \\ Mônica A. V. Petti ${ }^{1}$, Thaïs N. Corbisier ${ }^{1}$ \\ ${ }^{1}$ Oceanographic Institute, University of São Paulo, Praça do Oceanográfico 191, Cidade Universitária, São Paulo, SP, \\ CEP 05508-120, Brazil \\ ${ }^{2}$ Nuclear and Energy Research Institute (IPEN), Av. Lineu Prestes 2242, Cidade Universitária, São Paulo, SP, CEP 05508-000, Brazil \\ ${ }^{3}$ Present address: Fundacentro, Rua Capote Valente 710, São Paulo, SP, CEP 05409-002, Brazil
}

\begin{abstract}
This study was conducted on the continental shelf surrounding a large metropolitan region on the coast of São Paulo State, Southeast Brazil. This region harbours a large industrial plant and the largest port in Latin America, both of which release pollutants into the Santos-São Vicente estuarine system. High levels of $\mathrm{Hg}$ have been reported in sediments and fish from the estuaries and Santos Bay; however, data for the biota in offshore waters are scarce, and the biomagnification of $\mathrm{Hg}$ across the food web here has never been assessed. In this study, the trophic structure of the Santos shelf was addressed through the carbon and nitrogen stable isotope compositions of different species across a trophic gradient. We determined the total Hg levels (THg, dry weight) of invertebrates and fish to estimate the rate of biomagnification of this metal in the benthic and pelagic food webs. The lowest mean THg levels were found in zooplankton $\left(0.006 \mu \mathrm{g} \mathrm{g}^{-1}\right)$ and surface-depositivore polychaetes $\left(0.011 \mathrm{\mu g} \mathrm{g}^{-1}\right)$; the highest THg levels were found in the largest fishes: Patagonian flounder $\left(0.825 \mu \mathrm{g} \mathrm{g}^{-1}\right)$, fat snook $\left(0.714 \mu \mathrm{g} \mathrm{g}^{-1}\right)$, and lesser guitarfish $\left(0.639 \mathrm{ug} \mathrm{g}^{-1}\right)$. Overall, the Hg concentration in fish was below the recommended limit for human consumption. The THg and $\delta^{15} \mathrm{~N}$ were positively correlated in both food webs; however, the rate of biomagnification was higher and the basal $\mathrm{Hg}$ was lower in the pelagic food web. These differences may be related to the differing bioavailability of mercury in water and sediment, the higher diversity of prey and more complex feeding interactions in the benthic food web, and metabolic differences among different taxa.
\end{abstract}

KEY WORDS: Stable isotopes $\cdot$ Marine pollution $\cdot$ Trophodynamics $\cdot$ Southwest Atlantic

\section{INTRODUCTION}

The Baixada Santista is a large $\left(2402 \mathrm{~km}^{2}\right)$, densely populated metropolitan region on the coast of São Paulo State (southeastern Brazil) that comprises 9 municipalities along $246 \mathrm{~km}$ of coastline (CETESB 2006). The large industrial complex of Cubatão and the port of Santos (Fig. 1), which is the largest port in Latin America, introduce intense anthropogenic pressure along the coastal area. Consequently, high concentrations of metals, PCBs, and PAHs have been found in sediments of the estuarine system of the re- gion (Abessa et al. 2005, Bícego et al. 2006, Hortellani et al. 2008). The major potential sources of mercury $(\mathrm{Hg})$ contamination in this area are paper mills, the chemical, fertiliser, petrochemical, and steel industries, and the disposal of domestic wastes and contaminated sediments (CETESB 2001, Abessa et al. 2005, Buruaem et al. 2012). Navigation in and around the port often promotes high sedimentation rates requiring periodic dredging to maintain safe conditions for ship navigation. The dredged sediment is severely contaminated with $\mathrm{Hg}$ and is disposed in a $3.24 \mathrm{~km}^{2}$ area of open water (near Stns A3 and P9, see Fig. 1); 
Fig. 1. Sampling areas of invertebrates and fishes collected on the Santos continental shelf, southeastern Brazil, between 1 and 6 March 2006
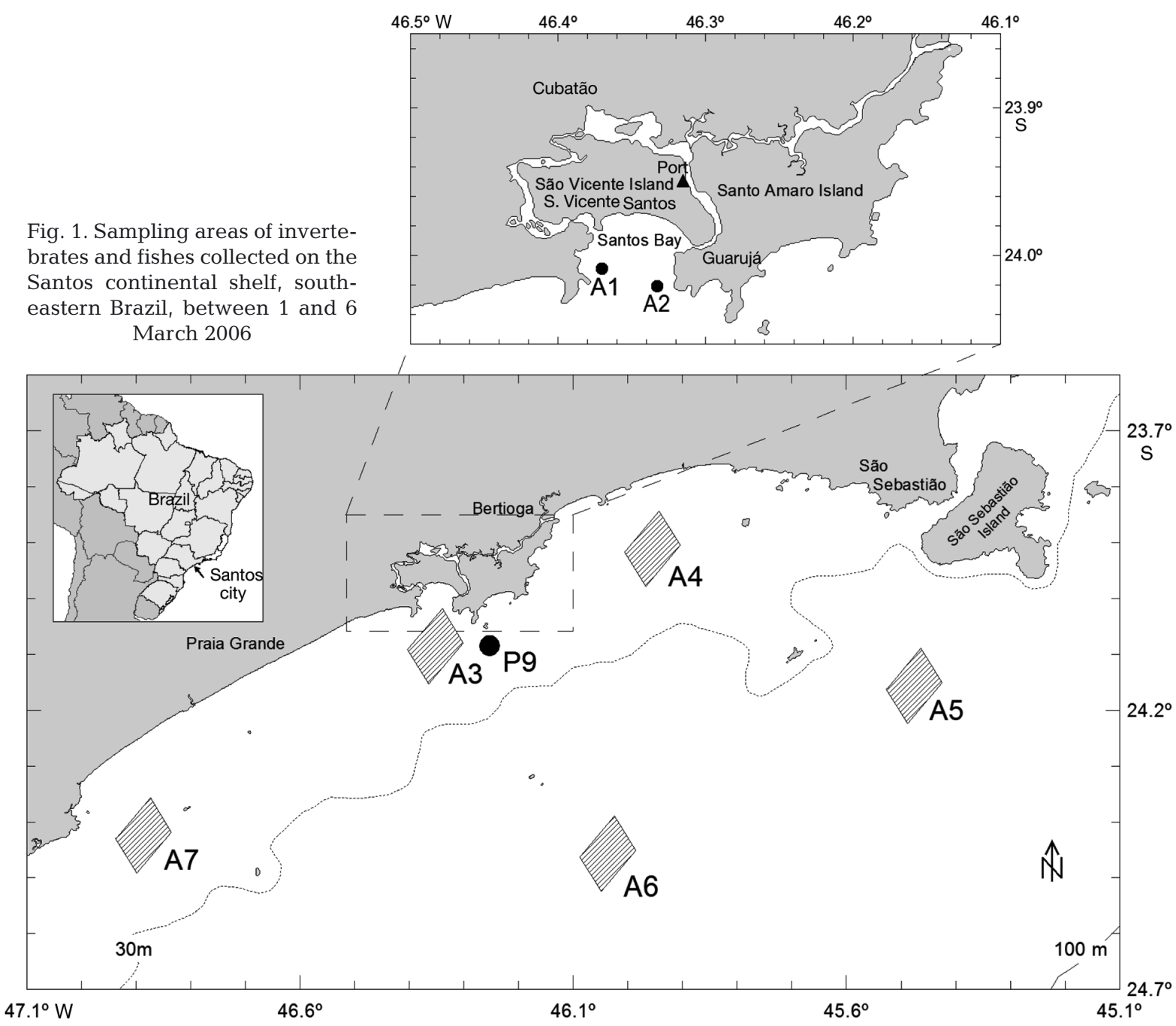

however, the toxicity of the sediment in the surrounding area is not significant because the contaminants disperse (Torres et al. 2009).

The continental shelf of Santos is an important fishery ground, accounting for $69.7 \%$ (16607 t) of the fish landings in São Paulo State in 2005 (Ávilada-Silva et al. 2007); therefore, understanding the dynamics of contaminants in the biological component of this system is of paramount importance. In Brazilian waters, high Hg levels have been reported in the bodies of top predators such as the swordfish Xiphias gladius and many shark species (Penedo de Pinho et al. 2002, Mársico et al. 2007, Dias et al. 2008). In the Santos-São Vicente estuary, sea catfish Cathorops spixii with $\mathrm{Hg}$ concentrations as high as $0.447 \mathrm{mg} \mathrm{kg}^{-1}$ wet weight have been found (Azevedo et al. 2012), while in Santos Bay, the Hg level can reach $0.11 \mathrm{mg} \mathrm{kg}^{-1}$ for this species (Azevedo et al. 2009).
In aquatic ecosystems, Hg enters a complex cycle controlled by competing simultaneous methylation and demethylation reactions (Bisinoti \& Jardim 2004, Rodríguez Martín-Doimeadios et al. 2004). Methylmercury (MeHg), the most toxic form of $\mathrm{Hg}$, usually comprises more than $85 \%$ of the total mercury (THg) in fish (May et al. 1987, Andersen \& Depledge 1997, Baeyens et al. 2003); therefore, human ingestion of fish is a significant pathway of $\mathrm{Hg}$ intake. Upon entering the food chain, MeHg can biomagnify effectively, increasing its concentration at each trophic level (Atwell et al. 1998, Kehrig et al. 2013).

A multidisciplinary project (ECOSAN) at the University of São Paulo was developed to evaluate the influence of the Santos-São Vicente estuarine system on the adjacent continental shelf. In the scope of this project, the trophodynamics of the demersal community were addressed using carbon and nitrogen stable isotopes (SI). Increasing knowledge of SI dynamics in 
the environment and biological systems has allowed the application of this tool in several fields of ecology. $\delta^{13} \mathrm{C}$ is used in food web studies to identify different sources of organic matter (Fry \& Sherr 1984, Peterson \& Fry 1987), benthic vs. pelagic producers and consumers, and nearshore vs. offshore feeding areas (France 1995, Sherwood \& Rose 2005, Chouvelon et al. 2012a). Because animals are usually 3-4\% enriched in heavy nitrogen $\left({ }^{15} \mathrm{~N}\right)$ relative to their diets (Minagawa \& Wada 1984, Peterson \& Fry 1987), this isotope is useful for identifying the trophic positions of organisms and for tracing contaminants in food webs (Rolff et al. 1993, Atwell et al. 1998, Campbell et al. 2005). This approach was used in the present study to quantify the rate of biomagnification of $\mathrm{Hg}$ in the pelagic and benthic food webs of the Santos continental shelf. In addition, the THg in fish muscles was evaluated to verify whether the concentrations exceed the level for human safe consumption.

\section{MATERIALS AND METHODS}

\section{Study area}

The estuaries of Santos and São Vicente are the primary sources of nutrients, suspended material, and phytoplankton to Santos Bay (Fig. 1); transport of these materials occurs mainly during the rainy season (Moser et al. 2005). Sediment sampling conducted in 2007 showed that Hg concentrations increase from Santos Bay to the inner portions of the estuary (Buruaem et al. 2013). According to criteria established by the Canadian Council of Ministers of the Environment (1999) and adopted by the Environmental Agency of São Paulo State (CETESB), excessive Hg concentrations in sediments (probable effect level greater than $0.70 \mu \mathrm{g} \mathrm{g}^{-1}$ ) occur in the inner part of the estuary. The sediment background of $\mathrm{Hg}$ for this estuarine system is $0.12 \pm 0.04 \mu \mathrm{g} \mathrm{g}^{-1}$ (Luiz-Silva et al. 2006). In Santos Bay, values above the threshold effect level of $0.13 \mu \mathrm{g} \mathrm{g}^{-1}$ occur near the submarine sewage outfall (Hortellani et al. 2005). No data are available for sediment, water, and biota in offshore waters of the Santos area.

The adjacent Santos continental shelf reaches $230 \mathrm{~km}$ in width and presents a slight declivity and shelf break at depths of 120 to $180 \mathrm{~m}$. It is divided into 3 areas: the inner, middle (usually less than $100 \mathrm{~m}$ depth), and outer shelves (Zembruscki 1979). The sediment of the inner and middle shelf is dominated by well-sorted fine and very fine sand (de Mahiques et al. 1999).
The high chlorophyll a concentrations recorded in the last $30 \mathrm{yr}$ in the estuarine system and Santos Bay characterise those areas as eutrophic (Ancona 2007). The oceanographic conditions of the shelf adjacent to Santos Bay change seasonally and can be classified as oligotrophic in terms of nutrient availability and phytoplankton biomass (Carvalho 2009). Along the southeast Brazilian coast, the cold, nutrient-rich South Atlantic Central Water moves toward the coast over the ocean bottom during spring and summer. The episodic upwelling of this water mass promoted by east-northeast winds enhances the local primary production (Castro Filho et al. 1987, Aidar et al. 1993).

\section{Sample collection and preparation}

All samples were collected during an oceanographic survey conducted during austral summer, from 1 to 6 March 2006. The sampling area included the Santos Bay and the adjacent continental shelf, both of which are under the influence of the Santos-São Vicente estuarine system (Fig. 1). The samples were taken from 2 sites located at the entrance of the Santos Bay (A1 and A2; depths of 8.9-11 m), 4 sites on the inner shelf (A3, A4, A7, and P9; depths of 19.8-26.5 m), and 2 sites on the middle shelf (A5 and A6; depths of 56-57 m; Fig. 1).

Zooplankton were sampled by oblique trawling using a Bongo net with a mesh size of $100 \mu \mathrm{m}$, sieved to obtain 4 size fractions (100-300, 300-625, 6251000, and $1000 \mu \mathrm{m})$, left for $6 \mathrm{~h}$ in seawater for gut cleaning, filtered in a glass-fibre filter (GFF), and frozen. Only the size fractions of 300-625 and 625-1000 $\mu \mathrm{m}$ contained enough mass to perform Hg determination.

The benthic macrofauna (polychaetes and bivalves) were collected using a van Veen grab and a box corer. Sediments were washed and the invertebrates that were retained in 1 and $2 \mathrm{~mm}$ mesh sieves were kept alive in an aquarium with filtered and aerated water for 12-24 h for gut cleaning, and then frozen. The megabenthos (shrimp, crabs, sea stars, ophiuroids, octopi, and gastropods) and nekton (fish and squid) were caught using a bottom otter trawl with a $17 \mathrm{~m}$ net (60 $\mathrm{mm}$ stretch mesh in the body and sleeve and $25 \mathrm{~mm}$ in the cod end). Hauls of 15 and $30 \mathrm{~min}$ at a speed of 2 knots were executed in Santos Bay and on the continental shelf, respectively. After identification, invertebrates and fish were frozen on board at $-20^{\circ} \mathrm{C}$.

Samples of fish dorsal muscles, squid and octopus mantle and arms, gastropod feet, shrimp abdomens, 
and crab pereiopods were taken for SI $\left(\delta^{13} \mathrm{C}\right.$ and $\left.\delta^{15} \mathrm{~N}\right)$ and $\mathrm{Hg}$ measurements. Oral discs were used for echinoderms samples, while polychaetes, zooplankton, and unshelled bivalves were prepared whole. Polychaetes were grouped into carnivores (Eunicidae, Glyceridae, Lumbrineridae, Polyodontidae), surface depositivores (Terebellidae), and subsurface depositivores (Capitellidae). With few exceptions, each sample of invertebrates and fish is a composite of several individuals of similar size. To measure the $\delta^{13} \mathrm{C}$ content of zooplankton, ophiuroids, and sea stars, additional samples were treated with concentrated $12 \mathrm{M}$ $\mathrm{HCl}$ fume in a desiccator to remove inorganic carbonates from carapaces (Harris et al. 2001). The samples were freeze-dried at $-30^{\circ} \mathrm{C}$ for $24 \mathrm{~h}$ (nekton) and $48 \mathrm{~h}$ (zooplankton, squid and benthic invertebrates) and powdered using a mortar and pestle.

\section{SI analysis}

The $\delta^{13} \mathrm{C}$ and $\delta^{15} \mathrm{~N}$ of the samples were measured using a continuous-flow isotope mass spectrometer (Europa 20/20-IRMS) coupled with an elemental analyser (PDZ Europa ANCA-GSL) at the Stable Isotope Facility of the University of California, Davis (USA). The standard reference materials were Vienna-PeeDee Belemnite (V-PDB) and atmospheric nitrogen $\left(\mathrm{N}_{2}\right)$ for $\delta^{13} \mathrm{C}$ and $\delta^{15} \mathrm{~N}$, respectively. The analytical precision derived from replicate measurements of internal laboratory standards run every 12 samples was $0.04 \%$ for $\delta^{13} \mathrm{C}$ and $0.20 \%$ for $\delta^{15} \mathrm{~N}$. SI ratios are denoted as parts per thousand (\%) deviation from the standard, as follows:

$$
\delta X(\%)=\left(R_{\text {sample }} / R_{\text {standard }}-1\right) \times 1000
$$

where $X$ is ${ }^{13} \mathrm{C}$ or ${ }^{15} \mathrm{~N}$ and the $R$ ratio is ${ }^{13} \mathrm{C} /{ }^{12} \mathrm{C}$ or ${ }^{15} \mathrm{~N} /{ }^{14} \mathrm{~N}$.

\section{Mercury analysis}

The THg concentrations of the organisms (dry weight, $\mu \mathrm{g} \mathrm{g}^{-1}$ ) were measured by cold vapour generation using an Atomic Absorption Spectrophotometer Varian (model Spectr-AAS-220-FS) at $253.7 \mathrm{~nm}$ (using the flow injection analysis-cold vapour-atomic absorption spectrometry [FIA-CV-AAS] technique). The spectrophotometer was coupled to a typical FIA manifold, with a manual valve that injects $500 \mu \mathrm{l}$ of digested sample with a flow of Milli-Q water $(10 \mathrm{ml}$ $\min ^{-1}$ ). The $\mathrm{Hg}^{2+}$ was reduced online by $\mathrm{SnCl}_{2} 25 \%$ $(\mathrm{m} / \mathrm{v})$ in $\mathrm{HCl} 25 \%(\mathrm{v} / \mathrm{v})$ at a flow rate of $1 \mathrm{ml} \mathrm{min}^{-1}$.
Argon was used as carrier gas at a constant flow rate of $150 \mathrm{ml} \mathrm{min}{ }^{-1}$ (Hortellani et al. 2005). The samples were digested in a $100 \mathrm{ml}$ volumetric flask containing $2 \mathrm{ml}$ of $\mathrm{H}_{2} \mathrm{SO}_{4}, 1 \mathrm{ml}$ of $\mathrm{HNO}_{3}, 1 \mathrm{ml}$ of $\mathrm{HClO}_{4}$, and $1 \mathrm{ml}$ of water per 0.4-1.2 $\mathrm{g}$ of sample (Azevedo et al. 2012). The mixture was heated for $30 \mathrm{~min}$ at $100^{\circ} \mathrm{C}$ on a hot plate. After cooling, the sample was transferred into a $30 \mathrm{ml}$ polypropylene flask, and the volume was increased to $20 \mathrm{~g}$ with high purity water obtained using the Milli-Q system of $18.2 \mathrm{M} \Omega \cdot \mathrm{cm}$ resistivity. Quality control was conducted through the analysis of CRM DORM2 (dogfish muscle) from the National Research Council, Ottawa, Canada, with a certified $\mathrm{Hg}$ content of $4.64 \pm 0.26 \mu \mathrm{g} \mathrm{g}^{-1}$. The measured value was $4.71 \pm 0.16 \mu \mathrm{g} \mathrm{g}^{-1}(\mathrm{~N}=3)$, which is in agreement with the certified value. The average recovery was $102 \pm 3.4 \%$. The accuracy rate was $1.51 \%$ and the $Z$ score was calculated according to the National Institute of Metrology, Quality and Technology (INMETRO 2007) $(|Z|=0.27)$. The detection limit (LD; $0.6 \mathrm{\mu g} \mathrm{l}^{-1}$ ) was based on the mean value obtained from 7 blank preparations $(\bar{X})$ plus 3 times the standard deviation ( $\mathrm{LD}=\bar{X}+3 \mathrm{SD}$ ). Each sample was run in duplicate, and coefficients of variation were less than $12 \%$. Blanks and check standards were run every 8 to 10 samples. The technique used in this study (FIA-CV-AAS) had an expanded uncertainty of $12.5 \%$ for total $\mathrm{Hg}$ and is accredited by the Coordenação Geral de Acreditação do Inmetro (CGCRE/ INMETRO 2013).

\section{Data analysis}

The means $( \pm \mathrm{SD})$ of $\mathrm{THg}$ concentrations $\left(\mu \mathrm{g} \mathrm{g}^{-1}\right.$ dry weight) and the SI compositions (\%) were calculated for each taxonomic group. The major food categories for invertebrates and fishes were defined according to stomach content analyses of squid and fish collected during the project (Muto et al. 2008, 2014, Chalom et al. 2008, Coelho et al. 2010) and/or from the literature. Based on that information, the organisms were assigned to the pelagic or benthic food web. Putative pelagic taxa included zooplankton, squid, zooplanktivore fishes (4 species), and the piscivore fishes Trichiurus lepturus (largehead hairtail), Merluccius hubbsi (Brazilian hake), and Percophis brasiliensis (Brazilian flathead). Benthic invertebrates (bivalves, gastropods, octopi, sea stars, ophiuroids, polychaetes, shrimp, and crabs), benthivore fishes (13 species), and benthic piscivore fishes (Paralichthys triocellatus, P. patagonicus, and Lophius gastrophysus) comprised the benthic food web. The 
mean $\delta^{13} \mathrm{C}$ and $\delta^{15} \mathrm{~N}$ values of those groups were plotted in a diagram to depict the food web structure on the Santos continental shelf.

To determine the rate of $\mathrm{Hg}$ transfer between trophic levels, a simple linear regression was performed between the logarithm of THg ( $\mu g g^{-1}$ dry weight) and $\delta^{15} \mathrm{~N}$ using data on individual samples of each taxon of invertebrates and fish. This analysis is analogous to the non-transformed equation of Rolff et al. (1993), where the parameter $a$ of the regression depends on the initial concentration of the element at the base of the food chain, allowing comparisons among systems with different levels of contamination. The slope value indicates the biomagnification of the element when $b>0$, i.e. the transfer of contaminants in each trophic level is more efficient than the transfer of biomass; conversely, $b<0$ denotes biodilution. The slope values were computed for the pelagic $(\mathrm{N}=75)$ and benthic $(\mathrm{N}=188)$ food webs as well for the full data set $(\mathrm{N}=263)$.

The food web biomagnification factor (FWMF), also referred as the trophic magnification factor (TMF), was obtained from the parameter $b$ of the equation $\log (\mathrm{THg})=a+\left(b \times \delta^{15} \mathrm{~N}\right)$ as follows: $\mathrm{FWMF}=10^{b}$ (Fisk et al. 2001). The original equation uses trophic levels instead of $\delta^{15} \mathrm{~N}$, but here we used $\delta^{15} \mathrm{~N}$ to infer the trophic position because of prey diversity and the uncertainty in the proportion of each prey consumed by each predator.

The slope values of the relationship between $\mathrm{THg}$ and $\delta^{15} \mathrm{~N}$ obtained from similar studies undertaken in other estuarine and marine regions of the world are summarised for comparison. For each study, we identified the primary producers or basal consumers sampled to classify the food web as pelagic (basal reference: particulate organic matter, phytoplankton, ice algae, seston, zooplankton) or benthic (basal reference: macroalgae, bivalves, amphipods, mysids), assuming that most of the top consumers are linked to the food chain derived from those food sources or their ecological equivalent. The food webs represented by both categories of basal organisms are denoted as 'pooled'.

\section{Statistical analyses}

Data on THg were $\log _{10}$-transformed to fit the assumptions of normal distribution and homoscedasticity. The Hg concentrations of groups of species of the pelagic and benthic food webs were compared through 1-way ANOVA using GraphPad Prism. Tukey's multiple comparison test was performed when- ever significant differences among samples were detected by ANOVA at $\mathrm{p}<0.05$. Gastropods, octopi, and sea stars were excluded from the analyses due to their small sample sizes.

The relationship between $\log (\mathrm{THg})$ and $\delta^{15} \mathrm{~N}$ was tested using a simple linear regression for each food web and for the overall data. If the regressions were significant, the slope values (rates of biomagnification) of the pelagic and benthic food webs were compared by analysis of covariance (ANCOVA) using $\delta^{15} \mathrm{~N}$ as the covariate. The general linear model routine of the statistical package Minitab 16 was used, and differences were considered to be statistically significant at $\mathrm{p}<0.05$.

\section{RESULTS}

A total of 263 samples were used for determination of SIs $\left(\delta^{13} \mathrm{C}\right.$ and $\left.\delta^{15} \mathrm{~N}\right)$ and THg of the biota, most of them represented by fish $(\mathrm{N}=174) \cdot \delta^{13} \mathrm{C}$ values of sea stars were omitted because the fumigation treatment failed to remove all carbonate from the samples $(\mathrm{N}=4)$. The details of the number of samples, dietary information, THg concentrations, SI signatures, food web assignments, size ranges of some organisms, and areas of sampling are presented in Table 1.

\section{Food web structure}

The mean $\delta^{13} \mathrm{C}$ of the organisms ranged from $-19.2 \%$ for the zooplanktivore fish Trachurus lathami to $-15.6 \%$ for the shrimp Xiphopenaeus kroyeri (Table 1). Bivalves and zooplankton had similar values, $-18.5 \pm 1.0$ and $-18.2 \pm 1.0 \%$, respectively. For $\delta^{15} \mathrm{~N}$, the mean values ranged from 6.9 to $13.9 \%$ (Table 1). Bivalves (suspensivores), zooplankton (suspensivores), surface-depositivore polychaetes, and ophiuroids (depositivores) had the lowest mean $\delta^{15} \mathrm{~N}$, representing the lowest trophic positions in the food web (Fig. 2). Subsurface-depositivore polychaetes had a mean $\delta^{15} \mathrm{~N}$ of $9.0 \%$, similar to that of shrimp (9.3$9.5 \%$ ), while carnivorous invertebrates displayed higher trophic positions $(>10.0 \%$ ). Zooplanktivorous fishes showed mean $\delta^{15} \mathrm{~N}$ values from 12.0 to $12.7 \%$, piscivores from 11.4 to $13.9 \%$, and benthivores from 10.4 to $13.5 \%$ o (Table 1 ).

The pattern of the SI signatures of suspended particulate organic matter (SPOM) sampled near the water surface and bottom (T. N. Corbisier pers. comm.) seemed to be followed by bivalves and zooplankton, especially for $\delta^{13} \mathrm{C}$ (Fig. 2). For the pelagic 


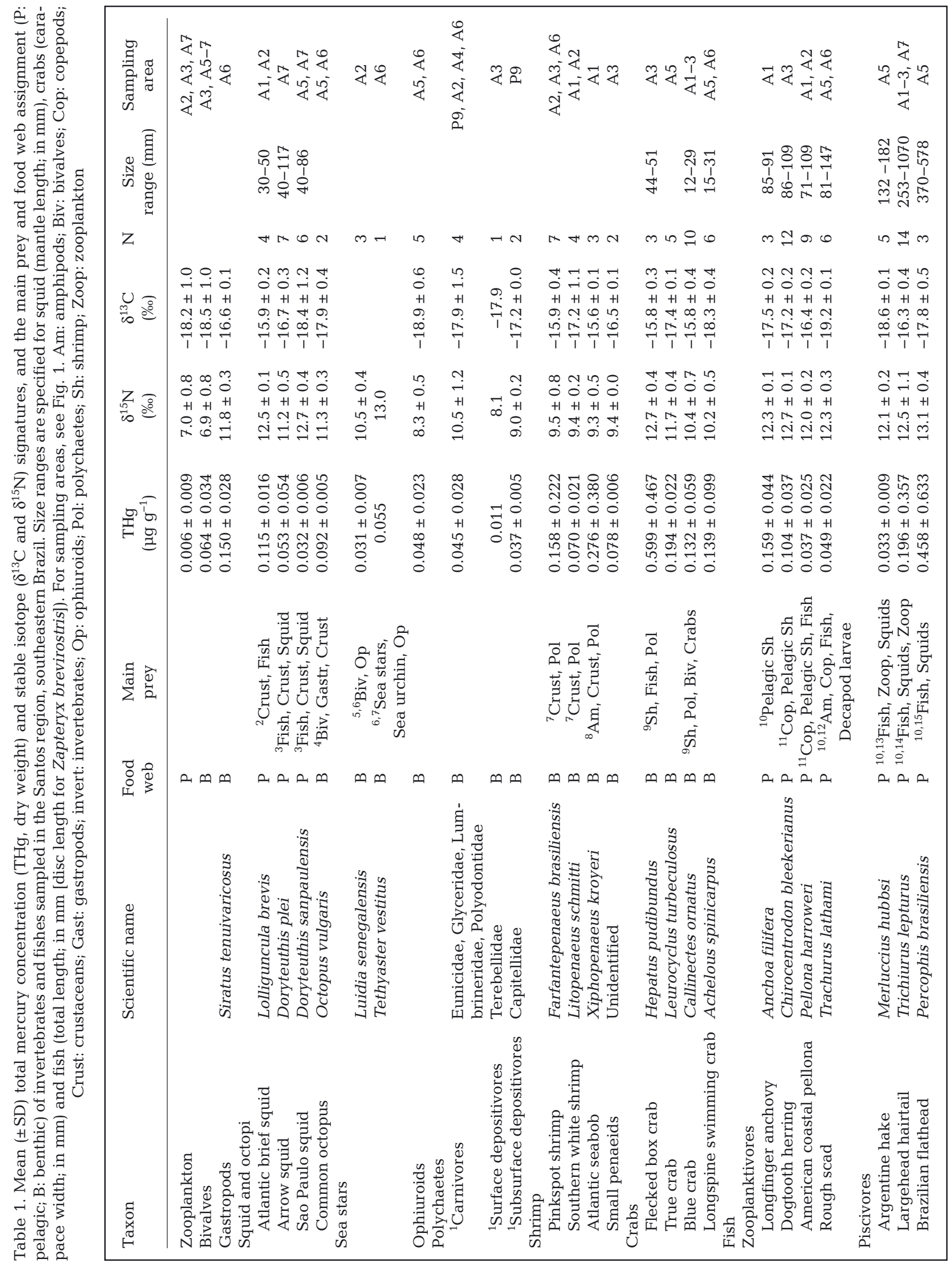




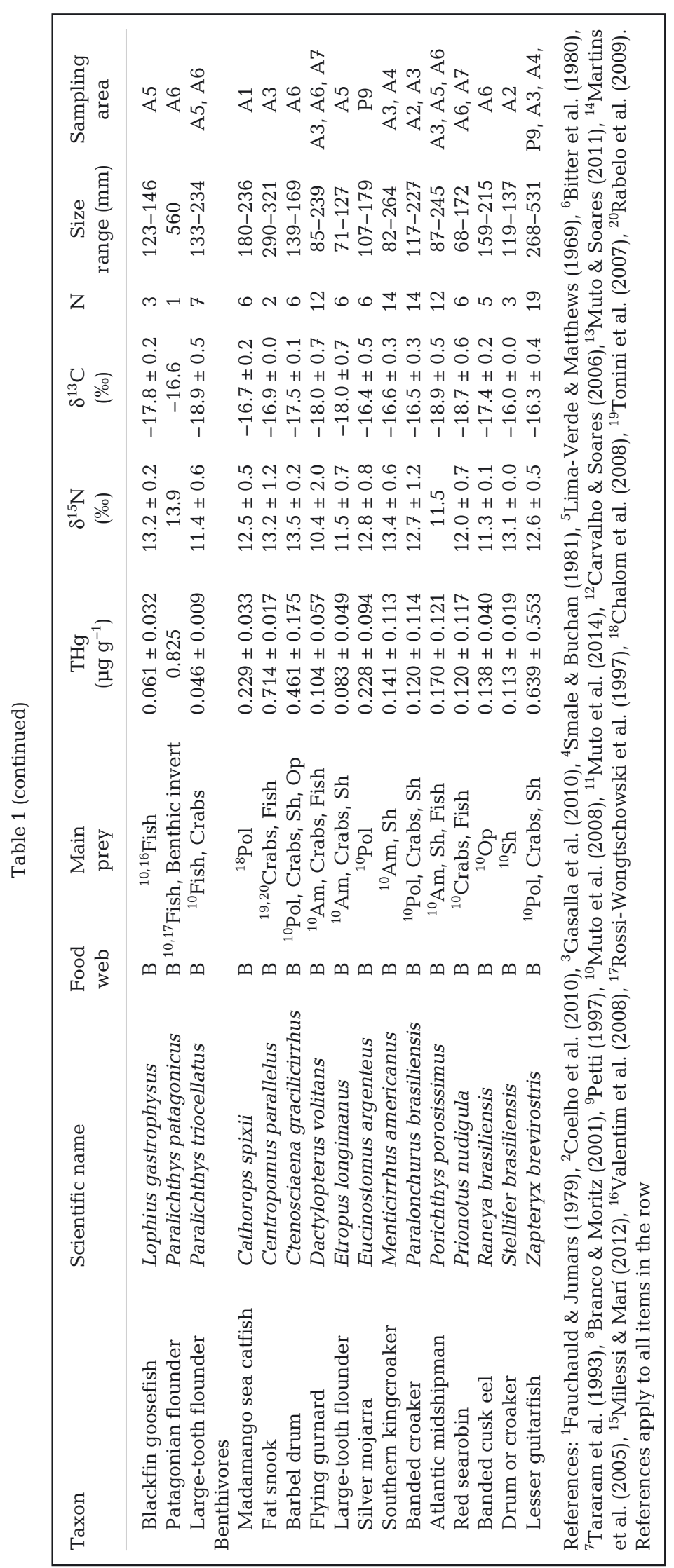

food web, both isotopes increased from the surface SPOM to zooplankton to top predators (squid and fish) (Fig. 2). The mean $\delta^{13} \mathrm{C}$ and $\delta^{15} \mathrm{~N}$ values of squid and zooplanktivorous and piscivorous fish were very similar to each other. For the benthic food web, increasing $\delta^{15} \mathrm{~N}$ values were observed from near-bottom SPOM to suspensivorous/detritivorous invertebrates to carnivorous invertebrates to fish. This trend was not as clear for $\delta^{13} \mathrm{C}$ : the suspensivorous/detritivorous invertebrates (amphipods, bivalves, and ophiuroids) were more enriched than the bottom SPOM and had the lowest signatures among the sampled animals, while shrimp had the highest $\delta^{13} \mathrm{C}$ values. Other carnivorous invertebrates and fish had intermediate values.

\section{Mercury}

The lowest mean THg occurred in zooplankton $\left(0.006 \mu^{-1} \mathrm{~g}^{-1}\right)$ and surface-depositivore polychaetes $\left(0.011 \mu \mathrm{g} \mathrm{g}^{-1}\right)$. The highest mean $\mathrm{THg}$ occurred in the Patagonian flounder $(0.825 \mu \mathrm{g}$ $\left.\mathrm{g}^{-1}\right)$, fat snook $\left(0.714 \mu \mathrm{g} \mathrm{g}^{-1}\right)$, lesser guitarfish $\left(0.639 \mu \mathrm{g} \mathrm{g}^{-1}\right)$, barbell drum $\left(0.461 \mu \mathrm{g} \mathrm{g}^{-1}\right)$, and Brazilian flathead $\left(0.458 \mu \mathrm{g} \mathrm{g}^{-1}\right)$. Those fishes, except for the barbell drum, were also the largest specimens sampled (Table 1). However, THg levels were highly variable within and among taxonomic groups of invertebrates and fish.

\section{Comparisons among invertebrates and fish groups}

The $\mathrm{Hg}$ concentrations of groups of invertebrates and fishes differed significantly for the pelagic (ANOVA: $F_{3,71}=19.1, \mathrm{p}<0.0001$ ) and benthic (ANOVA: $F_{6,173}=8.37, \mathrm{p}<0.0001$ ) food webs (Fig. 3). For the pelagic food web, squid (Tukey's test: $q=8.11, \mathrm{p}<0.001$ ), zooplanktivores $(q=9.58, \mathrm{p}<0.001)$, and piscivorous fishes $(q=10.50, \mathrm{p}<0.001)$ showed higher levels of THg than zooplankton but did not differ from each other. For the benthic food web, significant differences were found between benthivorous fishes and ophiuroids $(q=4.75, \mathrm{p}<$ $0.05)$, polychaetes $(q=6.80, \mathrm{p}<0.001)$, and piscivorous fishes $(q=4.99, \mathrm{p}<0.05)$. Crabs also had higher levels of $\mathrm{THg}$ than polychaetes $(q=$ $5.82, \mathrm{p}<0.01)$. 


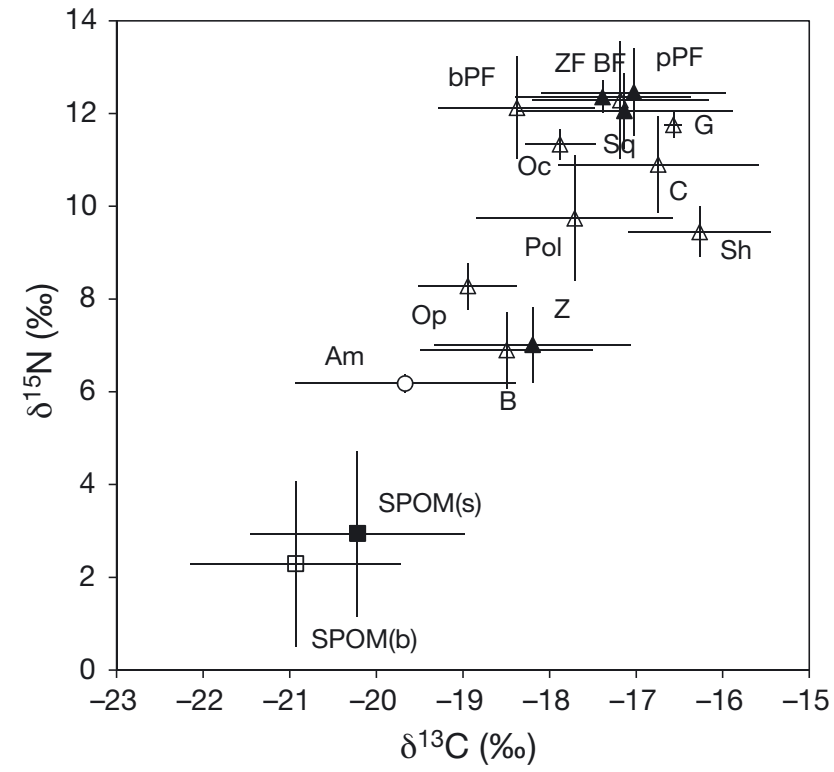

Fig. 2. Relationship between mean $( \pm \mathrm{SD}) \delta^{13} \mathrm{C}$ and $\delta^{15} \mathrm{~N}$ values of groups of organisms of the pelagic $(\mathbf{\Lambda})$ and benthic $(\Delta)$ food webs of the Santos continental shelf, during March 2006. Z: zooplankton; Sq: squid; ZF: zooplanktivore fish; pPF: pelagic piscivore fish; B: bivalves; Oc: octopi; G: gastropods; Op: ophiuroids; Pol: polychaetes; Sh: shrimp: C: crabs; BF: benthivore fish; bPF: benthic piscivore fish. Also shown are data on amphipods (O) and suspended particulate organic matter (SPOM, $\square, \square)$ collected near the water surface $(\mathrm{s}, \boldsymbol{\square})$ and bottom $(\mathrm{b}, \mathrm{a})$ during our sampling cruise (all sites, $\mathrm{N}=24$ ) are from $\mathrm{T}$. $\mathrm{N}$. Corbisier (pers. comm.)

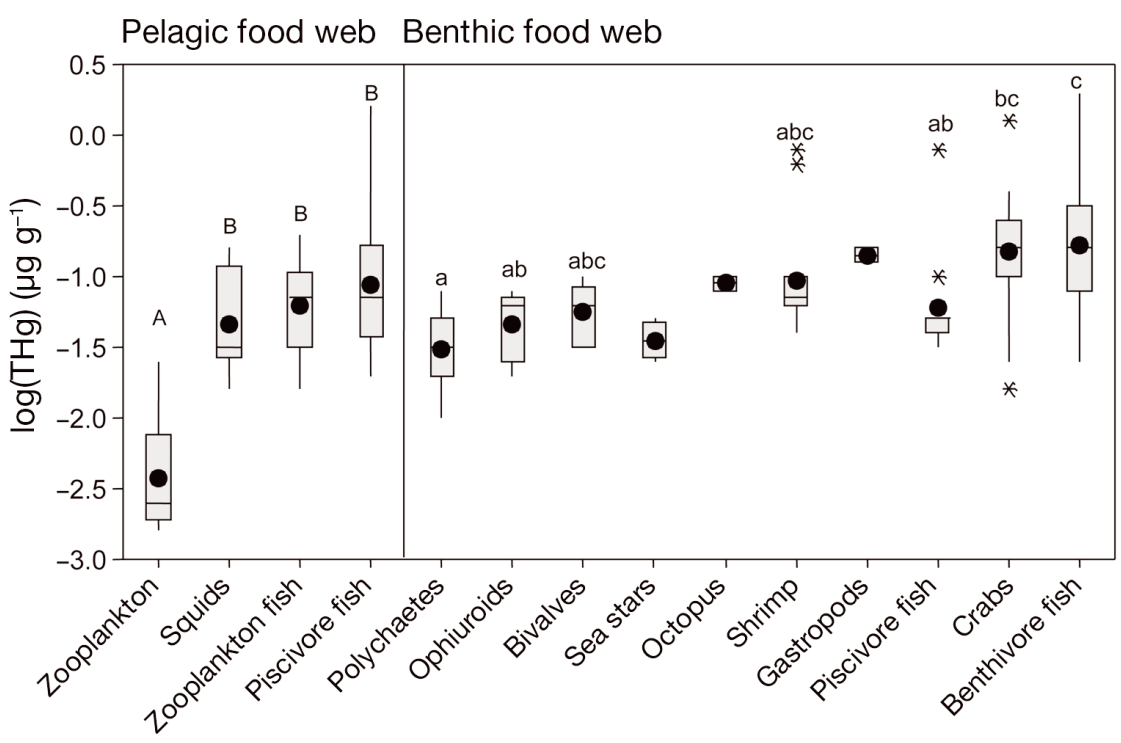

Fig. 3. Boxplot of log total mercury $(\log (\mathrm{THg})$; dry weight) as a function of groups of species of the pelagic and benthic food webs of the Santos continental shelf. Box length represents the interquartile range, bar length represents the range, horizontal lines are median values, closed circles are mean values, and the asterisks depict outliers. Groups sharing the same letter within the pelagic and benthic food webs are not significantly different

\section{Mercury transfer in the food web}

The THg concentrations increased according to the $\delta^{15} \mathrm{~N}$ values (trophic positions) of consumers, suggesting the biomagnification of this metal across the food web. The relationship between $\log (\mathrm{THg})$ and $\delta^{15} \mathrm{~N}$ was significant for both pelagic $(a=-4.23 \pm 0.29$, $b=0.25 \pm 0.02, \mathrm{R}^{2}=0.59$, $\mathrm{SE}$ of the regression $\left[s_{y X}\right]=$ $\left.0.337, F_{1,73}=104, \mathrm{p}<0.0001\right)$ and benthic $(a=-2.43 \pm$ $0.17, b=0.13 \pm 0.01, \mathrm{R}^{2}=0.31, s_{Y X}=0.352, F_{1,186}=$ 83.8, $\mathrm{p}<0.0001$ ) food webs, with a stronger relationship for the former (Figs. $3 \& 4$ ). The slope values of both regressions were statistically distinct (ANCOVA: $\left.F_{1,259}=15.78, \mathrm{p}=0.000\right)$. The FWMF was higher in the pelagic (1.8) than in the benthic food web (1.4), although the basal THg was higher in the latter. When organisms from both food webs were pooled (i.e. the full data set), the FWMF was 1.4, as derived from the linear regression $\log (\mathrm{THg})=0.15 \delta^{15} \mathrm{~N}-2.73$ $\left(a=-2.73 \pm 0.17, b=0.15 \pm 0.01, \mathrm{R}^{2}=0.28, s_{y X}=0.411\right.$ ， $\left.F_{1,261}=102.0, \mathrm{p}<0.0001\right)$.

\section{Comparisons among food webs worldwide}

The slope values of the total $\mathrm{Hg}$ concentrations versus $\delta^{15} \mathrm{~N}$ found in 14 studies (27 food webs) conducted in estuarine and marine waters ranged from 0.04 to 0.32 . The details of each study are presented in Table 2 to support the discussion.

\section{DISCUSSION}

\section{Food web structure}

The trophic gradient in the food webs of the Santos continental shelf was depicted by the $\delta^{15} \mathrm{~N}$ of the biota, representing at least 3 trophic levels. In the Gulf of St. Lawrence, benthic organisms were more enriched in $\delta^{13} \mathrm{C}$ than were benthopelagic and pelagic organisms (Lavoie et al. 2010); however, in our study, $\delta^{13} \mathrm{C}$ was not adequate to distinguish organisms from the pelagic and benthic food webs. Sediment collected at the same sites over the period of our sampling had $\delta^{13} \mathrm{C}$ signatures $(-22.03 \pm$ $1.27 \%$ ) less enriched compared with those found in SPOM sampled near 


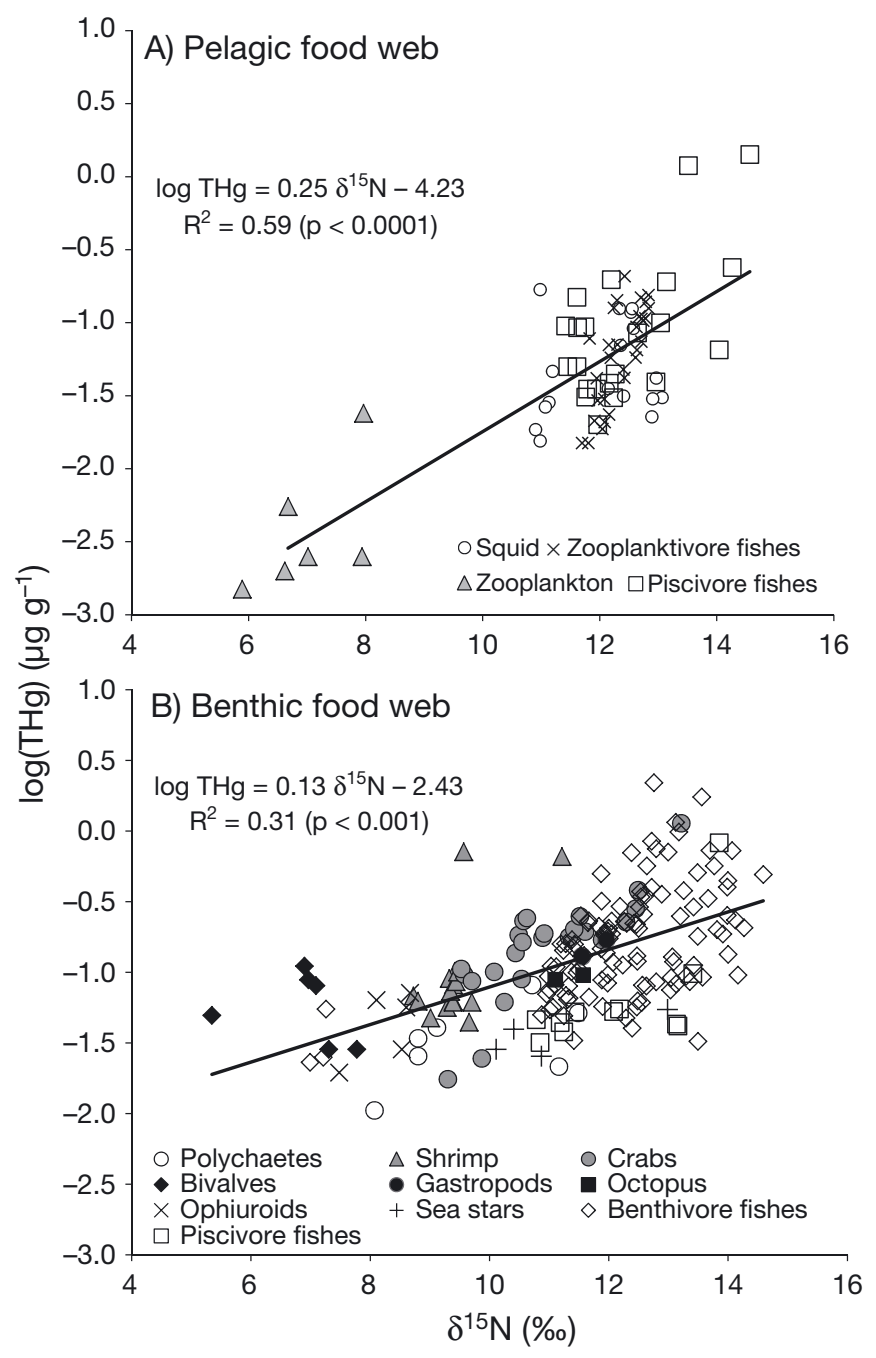

Fig. 4. Relationship between total mercury concentration $(\log (\mathrm{THg}))$ and trophic position $\left(\delta^{15} \mathrm{~N}\right)$ of representative organisms of the (A) pelagic $(\mathrm{N}=75)$ and (B) benthic $(\mathrm{N}=$ 188) food webs of the Santos shelf. Data points represent individual composite samples

the bottom $(-20.93 \pm 1.22 \%)$ and surface $(-20.22 \pm$ $1.24 \%$ ) (T. N. Corbisier pers. comm.). Although these small differences can be observed in lower-trophiclevel consumers, they become diluted farther up the food chain, most likely because carnivores have a wider food niche, especially in the benthic food web. Additionally, those values suggest that pelagic production may contribute to the benthos, as is expected in offshore waters where phytoplankton are the main primary producers. Indeed, the continental shelf of northern São Paulo State is dominated by pelagic production during the summer; however, the contribution of detritus is very significant, especially during the winter (Rocha et al. 2003, 2007). The high similarity between bivalve and zooplankton $\delta^{13} \mathrm{C}$ val- ues also suggests some degree of pelagic-benthic coupling, as observed in the Barents Sea (Tamelander et al. 2006).

The SI compositions of squid and planktivores and pelagic piscivorous fishes were very similar, most likely because they share similar prey at particular stages of their life cycles. Ontogenetic dietary shifts are common features in fish and squid; thus, changes in the trophic position with growth are expected. For instance, Trichiurus lepturus shift their diet from small crustaceans (copepods, mysids) to euphausiids, shrimp, squid, and fish as they grow (Martins et al. 2005). Adult Merluccius hubsi feed mainly on fish but small hakes also feed on euphausiids and amphipods (Muto \& Soares 2011). Although squid are voracious predators, the incidence of crustaceans in the stomach of small squid is higher than that in larger ones (Coelho et al. 2010, Gasalla et al. 2010). In contrast, small fish and squid can also be preyed on by larger individuals of Pellona harroweri and Chirocentrodon bleekerianus, respectively (Muto et al. 2008). Several benthivorous fish also undergo ontogenetic dietary changes, feeding on peracarid crustaceans and more sedentary invertebrates before changing their diets to decapods (mainly crabs) and fish (Muto 2004, Chalom et al. 2008, Marion et al. 2011). In the food web of Santos, low $\delta^{15} \mathrm{~N}$ signature of amphipods $(6.0-6.3 \%$ ) (T. N. Corbisier pers. comm.) was reflected in their predators, especially in fish (see Table 1). In summary, the average SI signatures tend to overlook the feeding variability in fish, unless the sample is composed of similarly sized individuals.

\section{Mercury in organisms}

As a whole, the biota of the Santos shelf had low $\mathrm{Hg}$ concentrations, comparable with values reported for the same species from the Rio de Janeiro coast (Bisi et al. 2012, Di Beneditto et al. 2012, Kehrig et al. 2013) and with species from others regions of the world (Prudente et al. 1997, Bargagli et al. 1998, Anan et al. 2005, Rigét et al. 2007, Ikemoto et al. 2008, Lavoie et al. 2010). Based on the assumption that marine fish are made up of $60-80 \%$ water (Ciancio et al. 2007, Eder \& Lewis 2005, Ikemoto et al. 2008) and the fact that our data are based on dry weight, the $\mathrm{Hg}$ concentrations of the 23 species analysed were under the set limit of $0.5 \mu \mathrm{g} \mathrm{g}^{-1}$ wet weight (approximately $1.67 \mu \mathrm{g} \mathrm{g}^{-1}$ dry weight, assuming $70 \%$ water) for safe fish consumption (WHO 1976, ANVISA 1998). Only 2 individual samples of the guitarfish had THg levels (1.74 and 
Table 2. Slope values of the linear regressions of logTHg vs. $\delta^{15} \mathrm{~N}$ and food web biomagnification factors (FWMF) from several studies performed in estuarine and marine waters around the world. POM: particulate organic matter; WW: wet weight; DW: dry weight

\begin{tabular}{|c|c|c|c|c|c|c|}
\hline Region & $\begin{array}{l}\text { Food } \\
\text { web }\end{array}$ & $\begin{array}{l}\text { Basal-top } \\
\text { predator }\end{array}$ & $\begin{array}{l}\text { Slope } \\
(b)\end{array}$ & $\begin{array}{c}\text { FWMF } \\
\left(10^{b}\right)\end{array}$ & Unity & Reference \\
\hline Baffin Bay, Arctic & Pelagic & Ice algae-Mammals & 0.20 & 1.57 & WW & Campbell et al. (2005) \\
\hline Chukchi Sea, Arctic & Benthic & Bivalves-Fish & 0.10 & 1.26 & DW & Fox et al. (2014) \\
\hline Lancaster Sound, Arctic & Pooled & POM-Mammals & 0.20 & 1.58 & DW & Atwell et al. (1998) \\
\hline West Greenland & Pooled & Zooplankton-Mammals & 0.18 & 1.52 & DW & Rigét et al. (2007) \\
\hline Baltic Sea & Pelagic & Plankton-Fish & 0.18 & 1.50 & WW & Nfon et al. (2009) \\
\hline \multirow{4}{*}{$\begin{array}{l}\text { Gulf of St. Lawrence, } \\
\text { Canada }\end{array}$} & Pooled & & 0.13 & 1.36 & DW & Lavoie et al. (2010) \\
\hline & Pelagic & POM-Seabirds & 0.22 & 1.65 & WW & Lavoie et al. (2010) \\
\hline & Benthopelagic & Bivalves-Seabirds & 0.19 & 1.56 & WW & Lavoie et al. (2010) \\
\hline & Benthic & Amphipods-Seabirds & 0.11 & 1.29 & WW & Lavoie et al. (2010) \\
\hline Nain Bay, Canada & Benthic & Algae-Fish & 0.11 & 1.29 & DW & van der Velden et al. (2013) \\
\hline Okak Bay, Canada & Benthic & Algae-Fish & 0.11 & 1.29 & DW & van der Velden et al. (2013) \\
\hline Saglek Bay, Canada & Benthic & Algae-Fish & 0.06 & 1.15 & DW & van der Velden et al. (2013) \\
\hline Dry Bay, Canada & Benthic & Algae-Fish & 0.06 & 1.15 & DW & van der Velden et al. (2013) \\
\hline Iqaluit, Canada & Benthic & Algae, Plankton-Fish & 0.13 & 1.35 & DW & van der Velden et al. (2013) \\
\hline Pound Inlet, Canada & Benthic & Algae-Fish & 0.13 & 1.35 & DW & van der Velden et al. (2013) \\
\hline $\begin{array}{l}\text { Gulf of the Farallones, } \\
\text { USA }\end{array}$ & Pelagic & Zooplankton-Mammals & $0.32^{\mathrm{a}}$ & 2.09 & DW & Jarman et al. (1996) \\
\hline $\begin{array}{l}\text { Ria de Aveiro coastal } \\
\text { lagoon, Portugal }\end{array}$ & Benthic & Algae-Fish & 0.04 & 1.10 & DW & Coelho et al. (2013) \\
\hline $\begin{array}{l}\text { Mekong Delta, } \\
\text { South Vietnam }\end{array}$ & Pooled & Phytoplankton-Fish & 0.10 & 1.26 & DW & Ikemoto et al. (2008) \\
\hline $\begin{array}{l}\text { Guanabara bay, Rio de } \\
\text { Janeiro, Brazil }\end{array}$ & Pooled & Seston-Mammals & 0.18 & 1.51 & WW & Bisi et al. (2012) \\
\hline $\begin{array}{l}\text { Sepetiba bay, Rio de } \\
\text { Janeiro, Brazil }\end{array}$ & Pooled & Seston-Mammals & $0.07^{b}$ & 1.17 & WW & Bisi et al. (2012) \\
\hline $\begin{array}{c}\text { Ilha Grande Bay, Rio } \\
\text { de Janeiro, Brazil }\end{array}$ & Pooled & Seston-Mammals & 0.22 & 1.66 & WW & Bisi et al. (2012) \\
\hline $\begin{array}{l}\text { Rio de Janeiro coast, } \\
\text { Brazil }\end{array}$ & Pooled & Phytoplankton-Fish & 0.25 & 1.76 & DW & Di Beneditto et al. (2012) \\
\hline $\begin{array}{l}\text { Rio de Janeiro coast, } \\
\text { Brazil }\end{array}$ & Pooled & Mesoplankton-Mammals & 0.21 & 1.62 & DW & Kehrig et al. (2013) \\
\hline \multirow{3}{*}{$\begin{array}{l}\text { Santos shelf, São Paulo, } \\
\text { Brazil }\end{array}$} & Pooled & & 0.15 & 1.41 & DW & Present study \\
\hline & Pelagic & Zooplankton-Fish & 0.26 & 1.82 & DW & Present study \\
\hline & Benthic & Bivalves-Fish & 0.13 & 1.35 & DW & Present study \\
\hline
\end{tabular}

$2.20 \mathrm{\mu g} \mathrm{g}^{-1}$ ) higher than this limit. However, a recent review on the effect of dietary $\mathrm{MeHg}$ on fish indicated adverse effects on reproduction as well as histological, biochemical, and genetic effects at concentrations below $0.2 \mathrm{\mu g} \mathrm{g}^{-1}$ wet weight (Depew et al. 2012). Some samples composed of large individuals of guitarfish, fat snoot, largehead hairtail, Patagonian flounder, and barbel drum from the Santos region had $\mathrm{Hg}$ concentrations of that magnitude; however, the health impact on these species at the population level is difficult to assess.

The Hg content in the biota of Santos differed among different types of invertebrates and fish; however, significant differences were detected only between some groups. This result may be linked to the high variability within species and among species of a particular group. In fact, the $\mathrm{Hg}$ concentration in demersal crustaceans increases with increasing trophic level (Asante et al. 2008) and is size-related in crabs, $\mathrm{MeHg}$ being the major form of $\mathrm{Hg}$ accumulated in muscle (Andersen \& Depledge 1997). The crabs of the Santos shelf showed the same pattern: larger species had higher $\delta^{15} \mathrm{~N}$ values and were more contaminated than were smaller species. In cephalopods, Hg mostly accumulates in muscle; the degree of contamination is related to the size and sex of Loliginidae squid (Bustamante et al. 2006). Because benthic species were more contaminated 
than pelagic species, those authors suggested that diet is not the main route for Hg uptake, as would be expected from the piscivore diet of the latter. Conversely, the high $\mathrm{Hg}$ concentration in the digestive glands (as well as muscles) of Octopus vulgaris supports a dietary source of $\mathrm{Hg}$ (Seixas et al. 2005). For polychaetes, feeding modes and depth position in sediment are stronger predictors of Hg contamination than trophic position; burrowing deposit-feeding polychaetes bioaccumulate more $\mathrm{MeHg}$ than carnivores do (Sizmur et al. 2013). On the Santos shelf, tissue $\mathrm{Hg}$ in polychaetes was higher in carnivores; however, subsurface depositivores had higher levels of $\mathrm{Hg}$ than did surface depositivores.

Food is the main source of MeHg exposure in wild fish (Hall et al. 1997) and high-trophic-level species tend to be more contaminated. As a whole, Hg levels are positively correlated to age, longevity, size, and weight, as a result of bioaccumulation over time (Andersen \& Depledge 1997, Adams et al. 2004, Anan et al. 2005, Lavoie et al. 2010, Payne \& Taylor 2010). Growth rate also affects the Hg content in fish: faster-growing fish have lower $\mathrm{Hg}$ concentration because of somatic dilution during rapid growth (Simoneau et al. 2005). In general, the most contaminated species of Santos shelf were the larger ones associated with high $\delta^{15} \mathrm{~N}$ values.

\section{Biomagnification of mercury across the food web}

On the Santos continental shelf, Hg concentrations in biota were related to $\delta^{15} \mathrm{~N}$ (trophic position); however, the stronger relationship found for the pelagic food web may be related to the small number of species analysed and/or to the narrower food niche in pelagic organisms. FWMF values greater than 1 indicate that $\mathrm{Hg}$ was transferred up the food web, though this occurs at different rates in the pelagic and benthic food webs.

In the estuaries of the Gulf of Maine, higher MeHg concentrations in the pelagic-feeding fauna suggest that feeding in or on sediments is less efficient for $\mathrm{MeHg}$ transfer than feeding on SPOM (Chen et al. 2009). Many studies comparing pelagic- and benthicfeeding fishes show a similar pattern. For instance, in a lacustrine system of Canada and in Manila Bay, fishes linked to the benthic food chain were less contaminated than those connected to the pelagic food chain (Prudente et al. 1997, Power et al. 2002). A comparison between 2 flatfish showed that species feeding on fish, squid, and macrocrustaceans had higher $\mathrm{Hg}$ concentrations than did species feeding on amphipods and polychaetes (Payne \& Taylor 2010). In contrast, and similar to our findings, an analysis of organisms across a wide depth range in the Bay of Biscay $(30-600 \mathrm{~m})$ showed that the pelagic fauna were less contaminated than the benthic and benthopelagic fauna (Chouvelon et al. 2012b). Demersal fish of the Antarctic inner shelf were more contaminated than epipelagic fish (Bargagli et al. 1998). The differences observed among those studies may be related to biological features of the analysed organisms or to the differential bioavailability of $\mathrm{Hg}$ in water and sediments in different systems. As a whole, benthic organisms of the Santos region were more contaminated than pelagic organisms, especially those at low trophic levels, suggesting the higher bioavailability of $\mathrm{Hg}$ in sediment than in water.

In the Gulf of St. Lawrence, the rates of $\mathrm{Hg}$ biomagnification decrease from pelagic $(0.22)$ to benthopelagic $(0.19)$ to benthic $(0.11)$ food webs and $\mathrm{Hg}$ concentrations at the base of the food chain were higher for the benthic system. This trend was attributed to the greater bioavailability of $\mathrm{Hg}$ to lowtrophic-level organisms feeding in deep waters and a more efficient transfer in the pelagic and benthopelagic chains. We found similar patterns in our study, and the differences observed between the 2 food webs on the Santos shelf may also be related to the higher complexity of the benthic-trophic interactions derived from the high diversity of potential prey with different feeding habits and the different metabolisms of benthic and pelagic organisms. The higher basal THg in the benthic food web of Santos is most likely associated with the higher bioavailability of $\mathrm{Hg}$ in the bottom sediments than in water; however, this hypothesis must be tested. Although we have addressed the biomagnification of $\mathrm{Hg}$ according to the main feeding habits of the biota, the pelagic and benthic domains are coupled, with several organisms (both prey and predators) displaying trophic vertical migration through the water column, such as zooplankton (Ashjian et al. 1998, Hays 2003), squid (Santos \& Haimovici 1998, Gasalla et al. 2010), and fish (Prenski \& Angelescu 1993, Martins et al. 2005). However, a separate examination of the pelagic and benthic food webs may help us to understand the trophodynamics of contaminants in different compartments of the system and should be considered in comparisons among food webs across latitudes.

To identify the main variables (physical, chemical, and biological) that affect $\mathrm{Hg}$ biomagnification in aquatic systems, a meta-analysis was performed on a large number of studies conducted in freshwater and 
marine regions worldwide (Lavoie et al. 2013). For marine sites, the average slope value was $0.20 \pm 0.10$ (mean $\pm \mathrm{SD})$, with no significant difference between THg and MeHg, coastal and offshore sites, or food web composition (inclusion of fish or proportion of endotherms). Polar and temperate sites had higher slope values than tropical sites, which is explained by slower excretion rates of $\mathrm{Hg}$ at cold temperatures and the dilution of tissue $\mathrm{Hg}$ due to enhanced growth rates in warmer waters. However, somatic growth dilution of an element is only effective when rapid growth is associated with a low efflux rate (excretion) (Karimi et al. 2010). Other studies have not found latitudinal differences in the biomagnification rates of $\mathrm{Hg}$ in marine and freshwater environments (Campbell et al. 2005, van der Velden et al. 2013)

The slope values for the pooled $(b=0.15)$, benthic $(b=0.13)$, and pelagic $(b=0.25)$ food webs of the Santos shelf were within the range $(0.04$ to 0.32$)$ of those observed in similar studies performed in estuarine and marine waters of a broad latitude range (Table 2). Those studies varied in the type of organisms sampled at the base and top of the food webs, metric (wet or dry weight), latitude, and feeding habitat (pelagic, benthopelagic, benthic, and pooled). Although we have not observed a trend in relation to the 3 first variables, the highest slope values occurred in the pelagic and pooled food webs, and most of the values for the benthic food webs were smaller than 0.013. Although Loseto et al. (2008) found similar values for benthic and pelagic food webs (0.23-0.26) in the Arctic, the beluga was the top predator in all food webs, and the details of the diet of this cetacean are still uncertain.

In conclusion, $\mathrm{Hg}$ is transferred across the pelagic and benthic food webs of the Santos continental shelf at different rates, being higher in the pelagic food web. Low-trophic-level benthic invertebrates were more prone to $\mathrm{Hg}$ accumulation than pelagic species, which is most likely associated with the higher availability of this metal in sediments than in water. Although the degree of contamination of fishes was bellow the set limit for safe human consumption, the monitoring of large specimens is advisable. Because low levels of $\mathrm{Hg}$ induce sublethal effects on fish, toxicological tests with different endpoints may improve our knowledge on the impact of $\mathrm{Hg}$ on the health and survival of the fish populations of Santos shelf. Finally, considering the many sources of anthropogenic pollution on the Santos coast, sediment, water, and biota should be monitored to detect longterm trends, especially for those contaminants that biomagnify in the food web.
Acknowledgements. The authors are grateful to the São Paulo Research Foundation (FAPESP) for the fellowship granted to E.Y.M. (FAPESP, Proc. 06/56974-0). The project ECOSAN was funded by CNPq/FAPESP-PRONEX (FAPESP proc. 2003/09932-1). We are grateful to the 3 anonymous reviewers for their constructive comments on the earlier version of the manuscript. We also thank Elisa K. Shibuya and Helena Miho Shihomatsu for technical and scientific support, Maria de Lourdes Zani Teixeira and Juliana Pierrobon Lopez for the map edition, and Lidia Paes Leme Arantes, Leandro Inoe Coelho, and André Chalom Machado de Oliveira for their support in the sampling work.

\section{LITERATURE CITED}

Abessa DMS, Sott Carr R, Rachid BRF, Souza ECPM (2005) Influence of Brazilian sewage outfall on the toxicity and contamination of adjacent sediments. Mar Pollut Bull 50: 875-885

Adams DH (2004) Total mercury levels in tunas from offshore waters of the Florida Atlantic coast. Mar Pollut Bull 49:659-663

Aidar E, Gaeta SA, Gianesella-Galvão SMF, Kutner, MBB, Teixeira C (1993) Ecossistema costeiro subtropical: nutrientes dissolvidos, fitoplâncton e clorofila-a e suas relações com as condições oceanográficas na região de Ubatuba, SP. Publção Esp Inst Oceanogr 10:9-43

Anan Y, Kunito T, Tanabe S, Mitrofanov I, Aubrey DG (2005) Trace element accumulation in fishes collected from coastal waters of the Caspian Sea. Mar Pollut Bull 51: 882-888

Ancona CM (2007) Aspectos da variação espacial e temporal da biomassa e produção fitoplantônica e parâmetros correlatos no estuário e baía de Santos. MSc dissertation, University of São Paulo, São Paulo, Brazil

Andersen JL, Depledge MH (1997) A Survey of total mercury and methylmercury in edible fish and invertebrates from Azorean waters. Mar Environ Res 44:331-350

ANVISA (1998) Legislação Brasileira, Portaria 685. Available at: http://portal.anvisa.gov.br/wps/wcm/connect/ 8c494f804745801a8c00dc3fbc4c6735/PORTARIA+N+\% $\mathrm{C} 2 \% \mathrm{BA}+685 \% 2 \mathrm{C}+\mathrm{DE}+27+\mathrm{DE}+\mathrm{AGOSTO}+\mathrm{DE}+1998$. pdf?MOD=AJPERES (accessed 30 Oct 2013)

- Asante KA, Agusa T, Mochizuki H, Ramu K and others (2008) Trace elements and stable isotopes $\left(\delta^{13} \mathrm{C}\right.$ and $\left.\delta^{15} \mathrm{~N}\right)$ in shallow and deep-water organisms from the East China Sea. Environ Pollut 156:862-873

Ashjian CJ, Smith SL, Flagg CN, Wilson C (1998) Patterns and occurrence of diel vertical migration of zooplankton biomass in the Mid-Atlantic Bight described by an acoustic Doppler current profiler. Cont Shelf Res 18: 831-858

Atwell L, Hobson KA, Welch HE (1998) Biomagnification and bioaccumulation of mercury in an arctic marine food web: insights from stable nitrogen isotope analysis. Can J Fish Aquat Sci 55:1114-1121

Ávila-da-Silva AO, Carneiro MH, Mendonça JT, Servo GJM, Bastos GCC, Batista PA (2007) Produção pesqueira marinha do Estado de São Paulo no ano 2005. Sér Relat Téc São Paulo 26:1-44

Azevedo JS, Fernandez WS, Farias LA, Fávaro DTI, Braga ES (2009) Use of Cathorops spixii as bioindicator of pollution of trace metals in the Santos Bay, Brazil. Ecotoxicology 18:577-586 
Azevedo JS, Sarkis JES, Hortellani MA, Ladle RJ (2012) Are catfish (Ariidae) effective bioindicators for $\mathrm{PB}, \mathrm{Cd}, \mathrm{Hg}$, $\mathrm{Cu}$ and $\mathrm{Zn}$ ? Water Air Soil Pollut 223:3911-3922

Baeyens W, Leermakers M, Papina T, Saprykin A and others (2003) Bioconcentration and biomagnification of mercury and methylmercury in North Sea and Scheldt Estuary fish. Arch Environ Contam Toxicol 45:498-508

- Bargagli R, Monaci F, Sanchez-Hernandez JC, Cateni D (1998) Biomagnification of mercury in an Antarctic marine coastal food web. Mar Ecol Prog Ser 169:65-76

Bícego MC, Taniguchi S, Yogui GT, Montone RC and others (2006) Assessment of contamination by polychlorinated biphenyls and aliphatic and aromatic hydrocarbons in sediments of the Santos and São Vicente Estuary System, São Paulo, Brazil. Mar Pollut Bull 52:1804-1816

Bisi TL, Lepoint G, Azevedo AF, Dorneles PR and others (2012) Trophic relationships and mercury biomagnification in Brazilian tropical coastal food webs. Ecol Indic 18: 291-302

Bisinoti MC, Jardim WF (2004) O comportamento do metilmercúrio (metilHg) no Ambiente. Quim Nova 27:593-600

Bitter RA, Molinet R, Penchaszadeh PE (1980) Interaccion trofica entre dos estrellas de mar (Astropecten riensis y Tethyaster vestitus) en golfo Triste, Venezuela. Bolm Inst Oceanogr Sao Paulo 29:61-63

Branco JO, Moritz Jr HC (2001) Alimentação natural do camarão sete-barbas, (Xiphopenaeus kroyeri), na Armação do Itapocoroy, Penha, SC. Rev Bras Zool 181:53-61

Buruaem LM, Hortellani MA, Sarkis JE, Costa-Lotufo LV, Abessa D (2012) Contamination of port zone sediments by metals from Large Marine Ecosystems of Brazil. Mar Pollut Bull 64:479-488

> Buruaem LM, Castro IB, Hortellani MA, Taniguchi S and others (2013) Integrated quality assessment of sediments from harbour areas in Santos-São Vicente Estuarine System, Southern Brazil. Estuar Coast Shelf Sci 130:179-189

Bustamante P, Lahaye V, Durnez C, Churlaud C, Caurant F (2006) Total and organic Hg concentrations in cephalopods from the North Eastern Atlantic waters: influence of geographical origin and feeding ecology. Sci Total Environ 368:585-596

Campbell LM, Norstrom RJ, Hobson KA, Muir DCG, Backus S, Fisk AT (2005) Mercury and trace elements in a pelagic Arctic marine food web. Sci Total Environ 351-352: 247-263

Canadian Council of Ministers of the Environment (1999) Canadian sediment quality guidelines for the protection of aquatic life: mercury. Canadian environmental quality guidelines, Winnipeg

Carvalho M (2009) Estimativa da concentração de clorofilaa através de dados de cor do oceano e caracterização oceanográfica da plataforma continental adjacente à Baía de Santos. PhD dissertation, University of São Paulo

Carvalho MR, Soares LSH (2006) Diel feeding pattern and diet of rough scad Trachurus lathami Nichols, 1920 (Carangidae) from the Southwestern Atlantic. Neotrop Ichthyol 4:419-426

Castro Filho BM, Miranda LB, Miyao SY (1987) Condições oceanográficas na plataforma continental ao largo de Ubatuba. Bolm Inst Oceanogr 35:135-151

CETESB (Environmental Agency of São Paulo State) (2001) Sistema Estuarino de Santos e São Vicente. Relatório Técnico, São Paulo, CETESB. Available at www.cetesb.sp. gov.br/agua/praias/25-publicacoes-/-relatorios (accessed 2 Feb 2014)
CETESB (Environmental Agency of São Paulo State) (2006) Relatório de Qualidade das Águas Litorâneas no Estado de São Paulo-Balneabilidade das Praias-2005. CETESB, São Paulo. Available at www.cetesb.sp.gov.br/ agua/praias/25-publicacoes-/-relatorios (accessed 2 Feb 2014).

CGCRE/INMETRO (2013) Accredited testing and calibration laboratories (RBLE and RBC). www.inmetro.gov.br/ laboratorios/rble/docs/CRL0242.pdf, revised in April/ March 2013 (accessed June 2014)

Chalom A, Muto EY, Soares LSH (2008) Variabilidade trófica na alimentação do bagre-amarelo Cathorops spixii (Agassiz, 1829) no litoral do estado de São Paulo. In: Braga ES (ed) Oceanografia e mudanças globais. Instituto Oceanográfico, São Paulo, p 257-272

Chen CY, Dionne M, Mayes BM, Ward DM, Sturup S, Jackson BP (2009) Mercury bioavailability and bioaccumulation in estuarine food webs in the Gulf of Maine. Environ Sci Technol 43:1804-1810

> Chouvelon T, Spitz J, Caurant F, Mèndez-Fernandez P and others (2012a) Revisiting the use of $\delta^{15} \mathrm{~N}$ in meso-scale studies of marine food webs by considering spatiotemporal variations in stable isotopic signatures - the case of an open ecosystem: the Bay of Biscay (North-East Atlantic). Prog Oceanogr 101:92-105

Chouvelon T, Spitz J, Caurant F, Mèndez Fernandez P, Autier J, Lassus-Débat A, Bustamante P (2012b) Enhanced bioaccumulation of mercury in deep-sea fauna from the Bay of Biscay (north-east Atlantic) in relation to trophic positions identified by analysis of carbon and nitrogen stable isotopes. Deep-Sea Res I 65:113-124

> Ciancio JE, Pascual MA, Beauchmp DA (2007) Energy density of Patagonian aquatic organisms and empirical predictions based on water content. Trans Am Fish Soc 136: 1415-1422

Coelho LI, Muto EY, Marian JEA, Soares LSH (2010) Contribuição ao conhecimento da dieta, atividade alimentar e reprodução de Lolliguncula brevis (Blainville, 1823) na região costeira de Santos (Estado de São Paulo). Bol Inst Pesca Sao Paulo 36:225-236

> Coelho JP, Mieiro CL, Pereira ME, Duarte AC, Pardal MA (2013) Mercury biomagnification in a contaminated estuary food web: effects of age and trophic position using stable isotope analyses. Mar Pollut Bull 69:110-115

> de Mahiques MM, Mishima Y, Rodrigues M (1999) Characteristics of the sedimentary organic matter on the inner and middle continental shelf between Guanabara Bay and São Francisco do Sul, southeastern Brazilian margin. Cont Shelf Res 19:775-798

> Depew DC, Basu N, Burgess NM, Campbell LM and others (2012) Toxicity of dietary methylmercury to fish: derivation of ecologically meaningful threshold concentrations. Environ Toxicol Chem 31:1536-1547

Di Beneditto APM, Bittar VT, Camargo PB, Rezende CE, Kherig HA (2012) Mercury and nitrogen isotope in a marine species from a tropical coastal food web. Arch Environ Contam Toxicol 62:264-271

> Dias ACL, Guimarães JRD, Malm O, Costa PAS (2008) Total mercury in muscle of the shark Prionace glauca (Linnaeus, 1758) and swordfish Xiphias gladius Linnaeus, 1758 , from the south-southeast coast of Brazil and the implications for public health. Cad Saude Publica 24: 2063-2070

Eder EB, Lewis MN (2005) Proximate composition and energetic value of demersal and pelagic prey species from 
the SW Atlantic Ocean. Mar Ecol Prog Ser 291:43-52

Fauchauld K, Jumars PA (1979) The diet of worms: a study of polychaete feeding guilds. Oceanogr Mar Biol Rev Camb Philos Soc 17:193-284

Fisk AT, Hobson KA, Norstrom RJ (2001) Influence of chemical and biological factors on trophic transfer of persistent organic pollutants in the Northwater Polynya marine food web. Environ Sci Technol 35:732-738

Fox AL, Hughesa EA, Trocinea RP, Trefrya JH and others (2014) Mercury in the northeastern Chukchi Sea: distribution patterns in seawater and sediments and biomagnification in the benthic food web. Deep-Sea Res II 102: $56-67$

France RL (1995) Carbon-13 enrichment in benthic compared to planktonic algae: foodweb implications. Mar Ecol Prog Ser 124:307-312

Fry B, Sherr EB (1984) $\delta^{13} \mathrm{C}$ measurements as indicators of carbon flow in marine and freshwater ecosystems. Contrib Mar Sci 27:13-47

Gasalla MA, Rodrigues AR, Postuma FA (2010) The trophic role of the squid Loligo plei as a keystone species in the South Brazil Bight ecosystem. ICES J Mar Sci 67: 1413-1424

Hall BD, Bodaly RA, Fudge RJP, Rudd JWM, Rosenberg DM (1997) Food as the dominant pathway of methylmercury uptake by fish. Water Air Soil Pollut 100:13-24

> Harris D, Horwáth WR, Kessel CV (2001) Acid fumigation of soils to remove carbonates prior to total organic carbon or carbon-13 isotopic analysis. Soil Sci Soc Am J 65:1853-1856

$>$ Hays GC (2003) A review of the adaptative significance and ecosystem consequences of zooplankton diel vertical migrations. Hydrobiologia 503:163-170

- Hortellani MA, Sarkis JES, Bonetti J, Bonetti C (2005) Evaluation of mercury contamination in sediments from Santos-São Vicente Estuarine System, São Paulo State, Brazil. J Braz Chem Soc 16:1140-1149

- Hortellani MA, Sarkis JES, Abessa DMS, Sousa ECPM (2008) Avaliação da contaminação por elementos metálicos dos sedimentos do estuário Santos-São Vicente. Quim Nova 31:10-19

- Ikemoto T, Tu NPC, Okuda N, Iwata A and others (2008) Biomagnification of trace elements in the aquatic food web in the Mekong delta, South Vietnam using stable carbon and nitrogen isotope analysis. Arch Environ Contam Toxicol 54:504-515

INMETRO (2007) Orientações sobre Validação de Métodos de Ensaios Químicos. DOQ-CGCRE-008. INMETRO, Rio de Janeiro

Jarman WM, Hobson KA, Sydeman WJ, Bacon CE, McLaren EB (1996) Influence of trophic position and feeding location on contaminant levels in the Gulf of the Farallones food web revealed by stable isotope analysis. Environ Sci Technol 30:654-660

Jaworski A, Ragnarsson SÁ (2006) Feeding habits of demersal fish in Icelandic waters: a multivariate approach. ICES J Mar Sci 63:1682-1694

Karimi R, Fisher NS, Folt CL (2010) Multielement stoichiometry in aquatic invertebrates: when growth dilution matters. Am Nat 176:699-709

Kehrig HA, Seixas TG, Malm O, Di Beneditto AP, Rezende CE (2013) Mercury and selenium biomagnification in a Brazilian coastal food web using nitrogen stable isotope analysis: a case study in an area under the influence of the Paraiba do Sul River plume. Mar Pollut Bull 75: 283-290
Lavoie RA, Hebert CE, Rail J, Braune BM, Yumvihoze E, Hill LG, Lean DRS (2010) Trophic structure and mercury distribution in a Gulf of St. Lawrence (Canada) food web using SIA. Sci Total Environ 408:5529-5539

- Lavoie RA, Jardine TD, Chumchal MM, Kidd KA, Campbell LM (2013) Biomagnification of mercury in aquatic food webs: a worldwide meta-analysis. Environ Sci Technol 47:13385-13394

Lima-Verde JS, Matthews HR (1969) On the feeding habits of the sea star Luidia senegalensis (Lamarck) in the state of Ceará (Brazil) Arq. Cienc Mar 9:173-175

Loseto LL, Stern GA, Deibel D, Connelly TL, Prokopowicz A, Lean DRS, Fortier L, Ferguson SH (2008) Linking mercury exposure to habitat and feeding behaviour in Beaufort Sea beluga whales. J Mar Sys 74:1012-1024

Luiz-Silva W, Matos RHR, Kristosch GC, Machado W (2006) Variabilidade espacial e sazonal da concentração de elementos-traço em sedimentos do sistema estuarino de Santos-Cubatão (SP). Quim Nova 29:256-263

> Marion C, Vaske-Junior T, Gadig OB, Martins I (2011) Feeding habits of the shortnose guitarfish, Zapteryx brevirostris (Müller and Henle, 1841) (Elasmobranchii, Rhinobatidae) in southeastern Brazil. Braz J Biol 71:83-89

Mársico ET, Machado MES, Knoff M, São Clemente SC (2007) Total mercury in sharks along the southern Brazilian coast. Arq Bras Med Vet Zootec 59:1593-1596

- Martins AS, Haimovici M, Palacios R (2005) Diet and feeding of the cutlassfish Trichiurus lepturus in the subtropical convergence ecosystem of southern Brazil. J Mar Biol Assoc UK 85:1223-1229

May K, Stoeppler M, Reising K (1987) Studies in the ratio total mercury methylmercury in the aquatic food-chain. Toxicol Environ Chem 13:153-159

Milessi AC, Marí N (2012) Ecología trófica del pez palo, Percophis brasiliensis (Quoy y Gaimard, 1825) en el ecosistema costero Argentino-Uruguayo $\left(34^{\circ} \mathrm{S}-41^{\circ} \mathrm{S}\right)$. Rev Invest Desarr Pesq 21:61-72

> Minagawa M, Wada E (1984) Stepwise enrichment of ${ }^{15} \mathrm{~N}$ along food chains: further evidence and the relation between ${ }^{15} \mathrm{~N}$ and animal age. Geochim Cosmochim Acta 48:1135-1140

Moser GAO, Gianesella SMF, Alba JJB, Bergamo AL, Saldanha-Correa FMP, Miranda LB, Harari J (2005) Instantaneous transport of salt, nutrients, suspended matter and chlorophyll-a in the tropical estuarine system of Santos. Rev Bras Oceanogr 53:115-127

Muto EY (2004) Variações isotópicas de ${ }^{13} \mathrm{C}$ e ${ }^{15} \mathrm{~N}$ de peixes demerso-pelágicos do ecossistema de plataforma ao largo de Cabo Frio (RJ) e Ubatuba (SP). PhD dissertation, Universidade de São Paulo, São Paulo

Muto EY, Soares LSH (2011) Diet and dual stable isotopes of the Argentine hake Merluccius hubbsi Marine, 1933 on the continental shelf of Southeastern Brazil. Mar Biol 158:1619-1630

Muto EY, Malfara DT, Coelho LI, Soares LSH (2008) Alimentação das sardinhas Pellona harroweri (Fowler, 1919) e Chirocentrodon bleekerianus (Poey, 1867), na região costeira de Santos, Estado de São Paulo. In: Braga ES (ed) Oceanografia e mudanças globais. Instituto Oceanográfico, São Paulo, p 287-302

Muto EY, Corbisier TN, Coelho LI, Arantes LPL, Chalom A, Soares LSH (2014) Trophic groups of demersal fish of Santos Bay and adjacent continental shelf, São Paulo State, Brazil: temporal and spatial comparisons. Braz J Oceanogr 62:89-102 
Nfon E, Cousins IT, Järvinen O, Mukherjee AB, Verta M, Broman D (2009) Trophodynamics of mercury and other trace elements in a pelagic food chain from the Baltic Sea. Sci Total Environ 407:6267-6274

Payne EJ, Taylor DL (2010) Effects of diet composition and trophic structure on mercury bioaccumulation in temperate flatfishes. Arch Environ Contam Toxicol 58:431-443

Penedo de Pinho AP, Guimarães JRD, Martins AS, Costa PAS, Olavo G, Valentin J (2002) Total mercury in muscle tissue of five shark species from Brazilian offshore waters: effects of feeding habit, sex, and length. Environ Res 89:250-258

> Peterson BJ, Fry B (1987) Stable isotopes in ecosystem studies. Annu Rev Ecol Syst 18:293-320

Petti MAV (1997) Papel dos crustáceos braquiúros na rede trófica da plataforma interna de Ubatuba, São Paulo (Brasil). Nerítica 11:123-137

> Power M, Klein GM, Guiger KRRA, Kwan MKH (2002) Mercury accumulation in the fish community of a sub-Artic lake in relation to trophic position and carbon sources. J Appl Ecol 39:819-830

Prenski LB, Angelescu V (1993) Ecología trofica de la merluza comun (Merluccius hubbsi) del mar Argentino. Parte 3. Consumo anual de alimento a nivel poblacional y su relación con la explotación de las pesquerías multiespecificas. INIDEP Documento Científico, Mar del Plata

> Prudente M, Kim E, Tanabe S, Tatsukawa R (1997) Metal levels in some commercial fish species from Manila Bay, the Philippines. Mar Pollut Bull 34:671-674

Rabelo LB, Muto EY, Soares LSH (2009) Observações preliminares do hábito alimentar do robalo flecha Centropomus undecimalis (Bloch, 1792) e robalo peba Centropomus parallelus Poey, 1860, no estuário de Caravelas (Bahia, Brasil). Bol Téc-Cient CEPENE 17:89-96

Rigét F, Møller P, Dietz R, Nielsen TG and others (2007) Transfer of mercury in the marine food web of West Greenland. J Environ Monit 9:877-883

Rocha GR, Rossi-Wongtschowski CLDB, Pires-Vanin AMS, Jarre-Teichmann A (2003) Seasonal budgets of organic matter in the Ubatuba shelf system, SE Brazil. I. Planktonic and benthic components. Oceanol Acta 26:487-495

Rocha GR, Rossi-Wongtschowski CLDB, Pires-Vanin AMS, Soares LSH (2007) Trophic models of São Sebastião Channel and continental shelf system, SE Brazil. Pananjas 2:149-162

Rodríguez Martín-Doimeadios RC, Tessier E, Amouroux D, Guyoneaud R, Duran R, Caumette P, Donard OFX (2004) Mercury methylation/demethylation and volatilization pathways in estuarine sediment slurries using speciesspecific enriched stable isotopes. Mar Chem 90:107-123

Rolff C, Broman D, Näf C, Zühr Y (1993) Potential biomagnification of $\mathrm{PCDD} / \mathrm{Fs}$ - new possibilities for quantitative assessment using stable isotope trophic position. Chemosphere 27:461-468

Rossi-Wongtschowski CLDB, Soares LSH, Muto EY (1997) A ictiofauna demersal do canal e da plataforma interna de
São Sebastião. Relat Téc Inst Oceanogr 41:47-64

Santos RA, Haimovici M (1998) Trophic relationships of the long-finned squid Loligo sanpaulensis on the southern Brazilian shelf. S Afr J Mar Sci 20:81-91

Seixas S, Bustamante P, Pierce G (2005) Accumulation of mercury in the tissues of the bottom Octopus vulgaris (L.) in two localities on the Portuguese coast. Sci Total Environ 340:113-122

> Sherwood GD, Rose GA (2005) Stable isotope analysis of some representative fish and invertebrates of the Newfoundland and Labrador continental shelf food web. Estuar Coast Shelf Sci 63:537-549

Simoneau M, Lucotte M, Garceau S, Laliberté D (2005) Fish growth rates modulate mercury concentrations in walleye (Sander vitreus) from eastern Canadian lakes. Environ Res 98:73-82

> Sizmur T, Canario J, Gerwing TG, Mallory ML, O'Driscoll NJ (2013) Mercury and methylmercury bioaccumulation by polychaete worms is governed by both feeding ecology and mercury bioavailability in coastal mudflats. Environ Pollut 176:18-25

Smale MJ, Buchan PR (1981) Biology of Octopus vulgaris off the East Coast of South Africa. Mar Biol 65:1-12

Tamelander T, Renaud PE, Hop H, Carroll ML, Ambrose WG Jr, Hobson KA (2006) Trophic relationships and pelagic-benthic coupling during summer in the Barents Sea Marginal Ice Zone, revealed by stable carbon and nitrogen isotope measurements. Mar Ecol Prog Ser 310: 33-46

Tararam AS, Wakabara Y, Equi MB (1993) Hábitos alimentares de onze espécies da megafauna bêntica da plataforma continental de Ubatuba, SP. Publção Esp Inst Oceanogr Sao Paulo 10:159-167

Tonini WCT, Braga LGT, Vila Nova DLD (2007) Dieta de juvenis do robalo Centropomus parallelus Poey, 1860 no sul da Bahia, Brasil. Bol Inst Pesca Sao Paulo 33:85-91

Torres RJ, Abessa DMS, Santos FC, Maranho LA, Davanso MB, Nascimento MRL, Mozeto AA (2009) Effects of dredging operations on sediment quality: contaminant mobilization in dredged sediments from the Port of Santos, SP, Brazil. J Soils Sediments 9:420-432

Valentim MFM, Caramaschi EC, Vianna M (2008) Feeding ecology of monkfish Lophius gastrophysus in the southwestern Atlantic Ocean. J Mar Biol Assoc UK 88: 205-212

> van der Velden S, Dempson JB, Evans MS, Muir DC, Power M (2013) Basal mercury concentrations and biomagnification rates in freshwater and marine food webs: effects on Arctic charr (Salvelinus alpinus) from eastern Canada. Sci Total Environ 444:531-542

WHO (1976) Environmental Health Criteria 1: mercury. World Health Organization, Geneva

Zembruscki SG (1979) Geomorfologia da margem continental sul brasileira e das bacias oceânicas adjacentes. In: Chaves HAF (ed) Geomorfologia da margem continental brasileira (Relatório Final). Série Projeto REMAC, 7, Rio de Janeiro, p 129-177

Proofs received from author(s): September 4, 2014 